\title{
Defining Social Class Across Time and Between Groups
}

\author{
Dov Cohen ${ }^{\mathrm{a}}$, Faith Shin ${ }^{\mathrm{a}}, \mathrm{Xi}$ Liu $^{\mathrm{a}}$, Peter Ondish ${ }^{\mathrm{a}}$, \& Michael W. Kraus ${ }^{\mathrm{b}}$ \\ a'University of Illinois at Urbana-Champaign \\ ${ }^{\mathrm{b}}$ Yale University
}

This manuscript has been accepted for publication at Personality and Social Psychology Bulletin, and the version that appears below may differ from the one that eventually appears in print at the journal. 


\begin{abstract}
We examined changes over four decades and between ethnic groups in how people define their social class. Changes included: the increasing importance of income; decreasing importance of occupational prestige; and the demise of the "Victorian bargain," in which poor people who subscribed to conservative sexual and religious norms could think of themselves as middle-class. The period also saw changes (among Whites) and continuity (among Black Americans) in subjective-status perceptions. For Whites (and particularly poor Whites), their perceptions of enhanced social class were greatly reduced. Poor Whites now view their social class as slightly but significantly lower than their poor Black and Latino counterparts. For Black respondents, a caste-like understanding of social class persisted, as they continued to view their class-standing as relatively independent of their achieved education, income, and occupation. Such achievement indicators, however, predicted Black respondents' self-esteem more than they predicted selfesteem for any other group.
\end{abstract}

Keywords: Social class; Culture; Socioeconomic Status; ethnic groups 
According to popular narrative, after World War II, America became a middle-class nation. More people went to college. More people owned their own homes. Wages rose (Reich, 2016).

This period from 1945 to the early-1970s has been called the "golden age of capitalism" (Marglin \& Schor, 1990). And according to historians, more Americans had a sense of themselves as “middle class," both economically and in terms of values, which were (up until the late-1960s) quite traditional.

This paper analyzes data from the tail-end of the golden age (1972) until 2010, examining people's changing conceptions of their own social class and place in society during the decades of post-boom wage stagnation. With resurgent interest in social class (A. Cohen \& Varnum, 2016; Fiske \& Markus, 2012; Stephens, Markus, \& Fryberg, 2012), psychologists have discovered the importance of people's subjective sense of standing for outcomes such as health and well-being (Adler et al., 2000), attention to self vs. others (Kraus, Piff, \& Keltner, 2009), and social and political attitudes (Brown-Iannuzzi, Lundberg, Kay, \& Payne, 2015). Below we examine some determinants of people's subjective social class, showing some ways these have changed or not changed over the past 40 years.

As will be seen, some factors shifted dramatically in importance whereas others hardly moved. We note in particular the large increase in the importance of income for people's sense of social class, the declining importance of occupational prestige, and the demise of a "Victorian bargain,” in which poor people who subscribed to traditional sexual and religious norms could see themselves as middle-class. We further note asymmetrical changes in America's caste-like racial status system. For Whites, and particularly poor Whites, the subjective status benefits of 
whiteness per se have declined. Poor whites now view their social class as slightly but significantly lower than that of their poor Latino and Black counterparts. In contrast, a caste-like understanding of social class persists among Black Americans. Compared to their counterparts, Black respondents’ subjective class remains relatively independent of their achievements in income and occupational prestige. These achievements do predict how Black respondents think about themselves (their self-esteem); they just do not (or do not much) predict Black Americans’ sense of their own standing in the larger society.

The current paper brings together existing strands of research. However, it also goes beyond earlier work either by using updated data or a longer time range of data, incorporating new variables and concepts, or by being explicitly comparative in its analysis of the four major U.S. “racial” groups (see, ex., Hout, 2008; Hunt \& Ray, 2012; Jackman \& Jackman, 1973). Given the dramatic ways in which the racial composition of the U.S. has changed over the last half-century (e.g., Craig \& Richeson, 2014a,b), a comparison of predictors of subjective class between racial groups can potentially yield important insights about the unique ways individuals of each group define their own (and their racial group’s) status attainment.

Of course, analytically it is common for researchers to “control for” race and status indicators in an attempt to disaggregate them. In reality, however, social class is frequently experienced in intersections with race-Black (African American) communities in the U.S., for example, tend to be poorer than White (nonHispanic European-American) communities, and upwardly-mobile Black Americans experience more obstacles to their ascendency relative to their White peers. This “intersectionality” makes empirical examinations of shifting race and class over time particularly valuable to a core understanding of social class. 
Class is in turn important to the study of mental health and well-being issues (Liu et al., 2004): Poverty is a major predictor of mental illness, and mid-life mortality rates among White nonHispanics, particularly those with a high-school education or less, are actually on the rise due in large part to suicides and poisoning or damage from drugs and alcohol (Case \& Deaton, 2015). We are not in a position to make causal claims in this paper. However, the decline in the physical and mental health of less-educated Whites is consistent with the broad trends in subjective status loss among poor Whites identified here.

Further, at the level of intergroup relations, changes over time in the declining subjective class perceptions of Whites and the relative continuity over time for Black respondents (who continue to understand social class as a caste-like status system in which they occupy the lower tier) seem to have implications for cross-group conflicts. Differing perceptions of social status seem relevant to perceptions of racism and to the racial resentments of the White working class that have allegedly become more important in politics, particularly the last election. Again, however, causal claims are beyond the scope here; and understanding how people construe social class has implications for political (and moral) attitudes that go beyond these concerns (Cote, Piff, \& Willer, 2013).

\section{Defining class}

Theorists discuss a number of factors relevant to defining class. These include objective resources (such as income and wealth), esteem and deference commanded by social roles (such as occupational prestige), education (important for human capital and networks), moral values (defining the kind of people I do vs. do not want to be associated with), style of life, taste, and caste (derived from ascribed group membership). A caste group is often difficult or impossible to 
leave and is frequently identified with visible markers (such as skin color) or certain social roles (Mahalingham, 2002).

All of these factors are thought to be related to each other. Income allows access to education, which is associated with entry into esteemed professions. Caste affects income, access to education, and interpersonal deference. And so on. Thus, separating out the various factors and looking at the "independent” influence of each has its difficulties. Nevertheless, there are some conceptual distinctions that can be made and related to our four main areas of inquiry about how people subjectively assess their social class.

\section{Changing importance of income, education, and occupational prestige over time}

The first main "hypothesis" - which has already been documented (Hout, 2008) - is that we expect income to be an increasingly important determinant of subjective class over the four decades. Though there is no definitive causal evidence for this, we expect that income has increased in importance since the early 1970s in part because median wages have stagnated. Income inequality also increased over this period (Piketty, 2014), with the GINI index of inequality hitting a post-war nadir in 1968 and then heading upward for most of the next 42 years. This means that income is likely the area where aspirations have grown the most but means have grown the least for average Americans. Further, the growing availability of consumer credit in the last 40 years means that Americans now borrow to purchase what they used to earn to purchase (Leicht, 2012), leading debt to become a salient source of stress and creating another reason for income to loom larger in people’s minds. Finally, as income inequality has increased and segregation by race has slowly decreased, income has become increasingly important as a determinant of housing (and thus schooling) segregation (Massey, Rothwell, \& Domina, 2009; Reardon, 2011). 
In contrast, we expect the importance of occupational prestige to have fallen as workplaces have (with the exception of pay) become more egalitarian - either because of "real" changes in organizational structure (flatter hierarchies, greater autonomy in work conditions) or greater informality and egalitarianism in workplace norms ("team-oriented" approaches, use of first names, dress codes, and so on) (Lazear \& Shaw, 2007; Osterman, 2014; Rajan \& Wulf, 2006). Greater workplace informality is probably part of a long-term trend going back further than the 1970s (Wouters, 2007), but even as late as 1975, etiquette books were still advising that a businessperson should "stand for his superiors" (Post, 1975, p. 748). A decrease in the importance of organizational prestige may also be related to the increased importance of income. Whereas salary and prestige are generally correlated, economist Robert Frank (1985) argues that in organizations where wages are compressed, organizations often retain high-performing employees by rewarding them with prestige or status (rather than paying them for their "worth" in money). Thus, in terms of compensation -- as money becomes more important and wages become less compressed (Lazear \& Shaw, 2008) -- deference, prestige, (and job security) should become less important or less readily provided to those already well-compensated.

Concerning education, years of schooling and the returns to schooling have increased over the past four decades (Marsden, 2012). To the extent that education has become increasingly important in ways not captured by salary alone (for example, for career trajectory or sense of distinction), we would expect the importance of education to have risen.

\section{Caste and subjective social class}

The second set of hypotheses has to do with race as diminishing over time in its association with subjective social class. There are two related issues here. The first has to do with a difference in the absolute level of subjective social class. If White and Black Americans have a 
sense that there is a caste ordering between them, we should see that, even when they have the same levels of income, education, and occupational prestige, Whites should view themselves as having higher subjective social class than Black respondents do. The second issue has to do with the sense that one's social standing is largely independent of one's actual achievements in education, income, and occupational prestige. Caste is ascribed and fixed across the life-course. Thus, if race in the U.S. operates in a caste-like way, one's actual achievements should matter little for one's sense of social standing in the larger society. Predictions here thus concern not the absolute level of subjective class but the degree to which it is predicted by achieved income, education, and occupational prestige. Consistent with other research (Jackman \& Jackman, 1973), we expect subjective class among Black respondents to be less predicted by income, education, and occupational prestige, as compared to other groups.

Over the past four decades, race has lost some of its caste-like properties. Continuing trends that began in the 1960s, Whites have become less likely to believe - or at least, admit they believe - Jim Crow-type sentiments that Black Americans are inferior; are less deserving of status, respect, and equal treatment; should be kept socially distant; and are peripheral to mainstream American life (Bobo, Charles, Krysan, \& Simmons, 2012; Norton \& Sommers, 2011; although cf., Richeson \& Sommers, 2016). We thus examine whether over time (a) Black vs. White differences in absolute level of subjective social class (controlling for “objective” factors such as income, education, and occupational prestige) would diminish and (b) Black respondents' sense of their social-class position would become increasingly predicted - or would remain underpredicted -- by their achieved levels of income, education, and occupational prestige (Wilson, 1990). 
It is important to note that we hypothesize that “objective” signs of achievement (income, education, occupational prestige) will affect how Black respondents feel about themselves, just as they are likely to affect how people of other groups feel about themselves. And this should be true even if these signs of achievement are only relatively weak predictors of how Black Americans view their social standing in the U.S. at large. Self-esteem is related to, but theoretically distinct from, subjective class (Twenge \& Campbell, 2002). As psychologists, we are accustomed to the idea that how we think about ourselves is highly tied-up with how we think others feel about us (as in Mead’s Generalized Other (1934), Smith’s impartial spectator (1759); or even the Clarks’ (1947) classic “doll” study). However, when members of a group know they are in a stigmatizing environment, they can disengage feelings of self-worth from those of social worth (Crocker, Major, \& Steele, 1998). Indeed, while we find that markers of achievement predict Black respondents' sense of social class relatively weakly, these same markers serve as strong predictors of Black respondents’ self-esteem.

Finally, the data also let us examine whether other nonWhite groups conceive of their social class in ways more similar to Black respondents or in ways more similar to Whites. This is an open question, but many scholars think the long history of race relations in the U.S. leads divisions between White and Black Americans to be qualitatively different than those between Whites and Latinos or Asian Americans (see Sears \& Savalei, 2006, on “Black exceptionalism”). Thus, for example, in terms of segregation (Massey et al., 2009), intermarriage (Wang, 2012), group identification (Duncan \& Trejo, 2016), and political attitudes (Pew, 2015), differences between Whites vs. Latinos and Asian Americans are far less pronounced than those between White vs. Black Americans. Similarly, for perceptions of social class, we expect that any “caste”-type effects will be less prevalent among Asian Americans and Latinos. 


\section{Traditional morality and subjective sense of status}

Morality has long been part of what defined the middle-class mindset. Victorian

reformers and American Protestant reformers in the $20^{\text {th }}$-century often aimed to help the poor by encouraging what they thought of as correct behavior (temperance, abstinence, thrift, religiosity, etc.). As Skeggs (2004, p. 29) has noted, definitions of “class” can alternate between being primarily economic vs. primarily moral, though the two are “rarely separable.” For $19^{\text {th }}$-and $20^{\text {th }}$-century Americans, participation in moral reform movements was a mark of middle-class standing (Boyer, 1978), abstinence a “symbol of middle-class membership” (Gusfield, 1986, p. 5), “sexual self-control” a “badge of middle-class status” (Murrin et al., 2015, p. 424), and religious revivalism a “part of the process of 'bourgeoisification,' a process in which the worker or the farmer takes on a middle-class (bourgeois) mode of life” (Gusfield, 1986, p. 46). In writing about “middle-class morality,” Hyslop-Margison (2008, p. 269) noted that “middle class” is a "somewhat ambiguous economic classification, but the values, morals, and aspirations defining the group are somewhat more constant.” Given how nebulously “middle class” is defined in terms of income, conformity to a certain moral code becomes a way of identifying oneself as middle class. Through endorsing Victorian or reformers' values, poor people could distinguish themselves from the "vulgarity" of those below them and become "middle class," even if they didn't have the economic means of those who were middle class by dint of income alone (Thompson, 1988, p. 260). Thus, we expected the endorsement of relatively traditional sexual and religious values to predict people's sense of their social class, with poor people holding such values being more likely to view themselves as middle class. Whether this bargain - adopting reformers' values as a way of establishing oneself as middle class - has deteriorated over the past 40 years is a question we explore. 


\section{Soft vs. hard predictors of social class among Black Americans}

It has been theorized that Black Americans define their social status based on different factors than Whites do (Hunt \& Ray, 2012), with, for example, community leadership and participation or family background being more important for Black respondents than for White respondents. We explored some of these hypothesized factors and find that some of these "soft" factors (for example, community involvement, family background) predict subjective class equivalently across groups, and that overall, these "soft” factors are as important as “objective indicators” in predicting subjective class among Black Americans - a pattern different from that of our other three ethnic groups.

\section{Method}

Data are from the GSS conducted between 1972 and 2010 (the latest available when we began; Smith, Marsden, \& Hout, 2011). With over 40,000 cases available for the main analysis, difficulties with statistical power should be slight. All items may be found in Supplementary Online Materials or ICPSR study 31521 codebook.

Our dependent variable - subjective social class -- was participants’ response to the question: "If you were asked to use one of the four names for your social class, which would you say you belong in: the lower class, the working class, the middle class, or the upper class?” (scored 1-4) $)^{1}$. This is a common measure of subjective class used in prior research (Kraus et al., 2012), though it differs from the MacArthur Scale of Subjective Social Status (a 10-rung unlabeled ladder with a preamble explicitly defining social status in terms of having the

\footnotetext{
${ }^{1}$ Three alternate versions of the main analysis reported in the text were run: 1 ) we re-ran the main analysis using logistic regression with lower- and working-class vs. Middle- and upperclass coded 0 vs. 1. 2) We nested observations within year and ran a multi-level model. 3) We excluded data from 2007-2010 to eliminate any distorting effects of the Great Recession. Results were very similar to those in the text, with the few exceptions noted in Supplementary Materials.
} 
most/least money, education, and respected jobs; Adler et al., 2000). Researchers, of course, must be careful when examining different operationalizations of the class variable. (However, see Supplementary Materials for analysis of American National Election Study data that substantially replicates the GSS results).

For our main independent variables, we operationalized relevant constructs only with questions that were asked for many years with no (or very minimal) changes.

\section{Independent Variables}

Income. Following Hout's recommendations (2004), we used income inflation-adjusted into year 2000 dollars, converted incomes less than $\$ 10,000$ into $\$ 10,000$, and log-transformed income, thus reducing skew.

Occupational prestige. Prestige scores were derived from earlier surveys asking respondents about the "social standing” that various occupations had. If there was a spouse, the spouse's occupational prestige was averaged with the respondent's to create a total measure for the household. Predictions were that occupational prestige would become less important in predicting subjective class.

Education. We used respondents' number of years of schooling. If there was a spouse, this was averaged with respondent's education to create a measure for the household.

Race. Race was measured as a categorical variable for whether respondents selfidentified as Black, White, Latino (Hispanic), or Asian². This categorical variable was turned into three dummy variables, with Whites as the omitted category.

\footnotetext{
${ }^{2}$ We coded for whether respondents were Black or White using the GSS race question that divided respondents into Black, White, or other. Respondents were coded as Asian if, in response to a question about where their ancestors came from, they answered China, Japan, Philippines, India or a country coded as “Other Asian.” Respondents were coded as Latino if their ancestors
} 
Because of the caste-like nature of race in the U.S., we expected that "objective" indicators (income, education, and occupational prestige) would be less predictive of subjective class among Black respondents, compared to Whites. However, we explored whether the importance of race per se as a predictor of subjective class would decrease over time, and whether the importance of income, education, and occupational prestige for Black respondents would come to more closely resemble that for Whites.

For the majority of analyses below, the number of Asian and Latino participants was relatively small (ns=711, 2636, respectively), compared to Black and White respondents (ns=5880, 35223). Before 1994, the number of Asian American respondents per year did not exceed 20. Estimates for Asian Americans in the survey’s early years should thus be treated warily and seen as an extrapolation of later trends. For Latinos, the number of respondents per year was at least 40, with a few exceptions, and it was never below 26.

Conventional morality. We created a measure of conventional morality that examined adherence to religion and to traditional norms of sexuality. Religion and sexual propriety have, for at least the last two centuries, been associated with reform movements aimed at the poor, who were deemed to be impulsive, licentious, and generally in need of self-control. Those without middle-class incomes could adopt conventional “middle-class” values and thus earn their status that way. The prediction was that poor people - particularly poor White and Black respondents who embraced these norms of conventional morality would be more likely to see themselves as middle class. It is an open question as to whether this "bargain" has remained in effect over the past four decades, as American society generally has become more secular and less traditional in its sexual attitudes (Grossmann \& Varnum, 2015).

came from Mexico, Puerto Rico, Spain, Portugal, a country coded as “Other Spanish,” or if they self-identified as Latino when this question was asked. 
The religiosity items asked about frequency of church attendance, frequency of prayer, respondents' self-rating about the intensity of their religiousness, and an attitudinal item about allowing prayer in schools. Items about conventional sexuality asked how strongly respondents disapproved of extramarital sex, teenage sex, premarital sex, homosexuality; how restricted pornography should be; and whether respondents had seen an x-rated movie. Items about religion and about sexuality were standardized and averaged together with equal weighting.

Age. We control for age and age $\times$ ethnicity interactions in the regressions. Though not of substantive interest here, age is correlated with subjective class as well as the independent variables of substantive interest.

A Note on Presentation. The main analysis is a single regression with all nonmissing cases from 1972 to 2010 (see Table 1). In figures, we plot predicted values for 1972 (-1.71 SDs from the mean for year) and 2010 (1.65 SDs from the mean). Because White is the omitted category, all b values in Table 1 not involving Black, Latino, or Asian American dummy variables represent simple slopes for Whites (i.e. the slopes when the value of all ethnicity dummy variables is 0 ). The three dummy variables by themselves indicate whether the average subjective class for each group is significantly different than that of Whites. For example, the b for the Black dummy variable of -0.151 is significant, implying that the average subjective class for Black respondents (2.456-0.151=2.305) is significantly different from that of Whites (2.456).

For interactions involving an ethnicity dummy and another variable $\mathrm{V}$, the interaction term indicates if the slope of the $\mathrm{V}$ variable for that ethnicity is significantly different from the simple slope of V for Whites. Thus, the significant Black dummy X income interaction (-0.088) indicates that the simple slope of income for Black respondents is $(0.177-0.088=0.089)$ and is significantly different from the simple slope of income for Whites (0.177). Nonsignificant 
interaction terms involving an ethnicity dummy $\mathrm{X}$ another variable $\mathrm{V}$ imply that the slope of $\mathrm{V}$ for that ethnicity is not significantly different from that for Whites.

Using Whites as the omitted category greatly lessens multicollinearity issues in the regression ${ }^{3}$. Where effects do not differ significantly between Whites and other groups, we generally use the coefficient for Whites (79\% of the sample) to indicate overall U.S. trends. Supplemental Materials show regression coefficients for each group run separately as well as collapsing over all groups; and, as may be seen, when there were no ethnicity interactions, results for Whites were similar to results for the nation as a whole. The only exceptions were that, in the analysis collapsing over all groups, the year X education and year X conventional morality interactions were significant, indicating that education and conventional morality have become less important over time as predictors of subjective class.

\section{Supplemental measures used in the reduced dataset}

Supplemental measures were not consistently asked over the four decades. Thus, sample sizes varied depending on the measure, and we treated analyses involving these variables as auxiliary to the main analysis.

Community engagement. Community engagement was a measure comprised of several smaller standardized indices asking about respondents’ involvement with community organizations and betterment projects (ex., a 5-item index of respondents’ involvement with various associations (religious groups, professional organizations, etc.); an index of 15 areas in which respondents may have done volunteer work; etc.)

\footnotetext{
3 Tolerances for all variables exceeded .26 if White was the omitted category (as in Table 1); tolerances would have gone as low as .09, .01, or .02 if Black, Latino, or Asian Americans, respectively, had been the omitted category.
} 
Family background. Respondents were asked about their parents’ education, parents’ occupational prestige, and whether their family income was "far below" to "far above" average when the respondent was 16-years-old. These three items were combined into an index.

Marital status. We dummy coded for whether respondents were currently married, ever married, or divorced.

Wealth estimate. Respondents were asked to estimate their "total wealth" with categories ranging from less than $\$ 5000$ to over $\$ 10$ million. This is likely not a very accurate estimate but it probably correlates with respondents' true wealth. (Unfortunately, the survey only asked about total wealth, rather than debts and assets separately).

Homeownership. Respondents indicated whether they owned or rented the place they lived.

Home relative to the neighborhood and relative to the city. Interviewers were asked to rate the place the respondent lived from far above to far below average. Ratings were made relative to the neighborhood and relative to others in the city.

Self-esteem. The 2004 survey included 5 items from Rosenberg's self-esteem scale (ex. “On the whole I am satisfied with myself.”)

\section{Results}

Predicted values (shown in figures and described in the text) are derived from the main regression table (Table 1), which shows coefficients, standard errors, and betas for all main effects and interactions.

Table 1. Regression Coefficients for the Main Independent Variables and Their Interactions Predicting Subjective Social Class 


\begin{tabular}{|c|c|c|c|}
\hline & $b$ & $S E b$ & $B$ \\
\hline (Constant) & 2.456 & & \\
\hline GSS year for this respondent (year) & -0.070 & 0.003 & $-0.106 * * *$ \\
\hline Income & 0.177 & 0.004 & $0.272 * * *$ \\
\hline Occupational prestige & 0.058 & 0.004 & $0.089 * * *$ \\
\hline Education & 0.162 & 0.004 & $0.247 * * *$ \\
\hline Conventional morality & 0.001 & 0.003 & 0.001 \\
\hline Black & -0.151 & 0.010 & $-0.079 * * *$ \\
\hline Latino & -0.063 & 0.015 & $-0.024 * * *$ \\
\hline Asian American & -0.017 & 0.029 & -0.003 \\
\hline Income $\times$ Conventional morality & -0.017 & 0.003 & $-0.026 * * *$ \\
\hline Year $\times$ Income & 0.033 & 0.004 & $0.050 * * *$ \\
\hline Year $\times$ Occupational prestige & -0.012 & 0.004 & $-0.018 * *$ \\
\hline Year $\times$ Education & -0.006 & 0.004 & -0.010 \\
\hline Year $\times$ Conventional morality & -0.001 & 0.003 & -0.002 \\
\hline Year $\times$ Income $\times$ Conventional morality & 0.012 & 0.003 & $0.019 * * *$ \\
\hline Black $\times$ Year & 0.059 & 0.010 & $0.032 * * *$ \\
\hline Latino $\times$ Year & 0.028 & 0.013 & $0.012 *$ \\
\hline Asian American $\times$ Year & -0.004 & 0.028 & -0.001 \\
\hline Black $\times$ Income & -0.088 & 0.010 & $-0.051 * * *$ \\
\hline Latino $\times$ Income & -0.012 & 0.015 & -0.005 \\
\hline Asian American $\times$ Income & 0.009 & 0.029 & 0.002 \\
\hline Black $\times$ Occupational prestige & -0.038 & 0.010 & $-0.023 * * *$ \\
\hline Latino $\times$ Occupational prestige & 0.011 & 0.016 & 0.004 \\
\hline Asian American $\times$ Occupational prestige & 0.050 & 0.028 & $0.013 \mathrm{~m}$ \\
\hline Black $\times$ Education & -0.099 & 0.011 & $-0.058 * * *$ \\
\hline Latino $\times$ Education & -0.091 & 0.014 & $-0.042 * * *$ \\
\hline Asian American $\times$ Education & -0.136 & 0.032 & $-0.034 * * *$ \\
\hline Black $\times$ Conventional morality & 0.010 & 0.009 & 0.005 \\
\hline Latino $\times$ Conventional morality & 0.001 & 0.014 & 0.000 \\
\hline Asian American $\times$ Conventional morality & -0.021 & 0.026 & -0.005 \\
\hline Black $\times$ Income $\times$ Conventional morality & -0.016 & 0.009 & $-0.009 \mathrm{~m}$ \\
\hline
\end{tabular}




\begin{tabular}{|c|c|c|c|}
\hline Latino $\times$ Income $\times$ Conventional morality & 0.028 & 0.014 & $0.010 *$ \\
\hline Asian American $\times$ Income $\times$ Conventional morality & -0.024 & 0.027 & -0.006 \\
\hline Year $\times$ Black $\times$ Income & -0.004 & 0.010 & -0.002 \\
\hline Year $\times$ Latino $\times$ Income & -0.037 & 0.014 & $-0.015 * *$ \\
\hline Year $\times$ Asian American $\times$ Income & -0.025 & 0.030 & -0.006 \\
\hline Year $\times$ Black $\times$ Occupational prestige & 0.007 & 0.010 & 0.004 \\
\hline Year $\times$ Latino $\times$ Occupational prestige & 0.001 & 0.015 & 0.000 \\
\hline Year $\times$ Asian American $\times$ Occupational prestige & -0.001 & 0.028 & 0.000 \\
\hline Year $\times$ Black $\times$ Education & -0.009 & 0.010 & -0.006 \\
\hline Year $\times$ Latino $\times$ Education & 0.001 & 0.013 & 0.001 \\
\hline Year $\times$ Asian American $\times$ Education & 0.009 & 0.031 & 0.002 \\
\hline Year $\times$ Black $\times$ Conventional morality & -0.016 & 0.009 & $-0.009 \mathrm{~m}$ \\
\hline Year $\times$ Latino $\times$ Conventional morality & 0.003 & 0.013 & 0.001 \\
\hline Year $\times$ Asian American $\times$ Conventional morality & -0.045 & 0.026 & $-0.010 \mathrm{~m}$ \\
\hline Year $\times$ Black $\times$ Income $\times$ Conventional morality & -0.007 & 0.009 & -0.004 \\
\hline Year $\times$ Latino $\times$ Income $\times$ Conventional morality & -0.027 & 0.013 & $-0.011 *$ \\
\hline $\begin{array}{l}\text { Year } \times \text { Asian American } \times \text { Income } \times \text { Conventional } \\
\text { morality }\end{array}$ & 0.040 & 0.026 & 0.011 \\
\hline Age & 0.125 & 0.003 & $0.186 * * *$ \\
\hline Age $\times$ Black & -0.058 & 0.010 & $-0.030 * * *$ \\
\hline Age $\times$ Latino & -0.067 & 0.015 & $-0.023 * * *$ \\
\hline Age $\times$ Asian American & -0.068 & 0.027 & $-0.012 *$ \\
\hline
\end{tabular}

Notes: $n=44894, R^{2}=0.224$. $* p \leq 0.05, * * p \leq 0.01, * * * p \leq 0.001$, all two-tailed.

The first term in the regression is year (Table 1). There is no zero-order correlation between year and subjective class ( $\mathrm{r}=-0.006)$. However, over the past 40 years, Americans have, on average, become more educated, held more prestigious jobs, and had somewhat higher household incomes (correlations between year and education, occupational prestige, and household income were $0.22,0.17$, and 0.07 , all $\mathrm{ps}=0.001$ ). So controlling for those factors makes the "net" effect of year significantly negative. 
This indicates that: 1) Expectations of what it means to be middle-class have risen in a world where people have more education, more prestigious jobs, and higher household income. And consequently, 2) at any given level of income, education, or job prestige, a person’s subjective sense of social class is lower in 2010 than it was in 1972. As will be seen, these effects, combined with others below, have led to particularly large subjective status losses among poor Whites.

\section{Growing importance of income, declining importance of occupational prestige}

In terms of overall trends, the importance of income, education, and occupational prestige for people's sense of their own social class has changed over the past 4 decades (Figure 1; Table 1). Shifts were most pronounced for Whites, with prestige slightly diminishing in importance, education staying about the same, and income massively increasing in importance. For 1972 (1.71 SDs below the mean for year), the $b$-values for the standardized prestige, education, and income variables would be 0.08, 0.17, and 0.12, respectively. In 2010 (1.65 SDs above the mean), the $b$-values for the standardized prestige, education, and income variables would be 0.04, 0.15, and 0.23, respectively. Figure 1 panel a shows the three effects among Whites for 1972; panel b shows the three effects for 2010. Thus, for Whites in 1972, education would have been the most important variable with income second. By the 2010 GSS, income had clearly become the most important variable. Occupational prestige became clearly the least important.

The ascent of income is also clearly shown for Black respondents (Figure 1, row 2), with income now well surpassing education as the most important variable predicting subjective class. For Latinos and Asian Americans, income began and ended the four decades as the most important variable. Thus, by the 2010 GSS, income had become the most important variable predicting social class for all groups. 

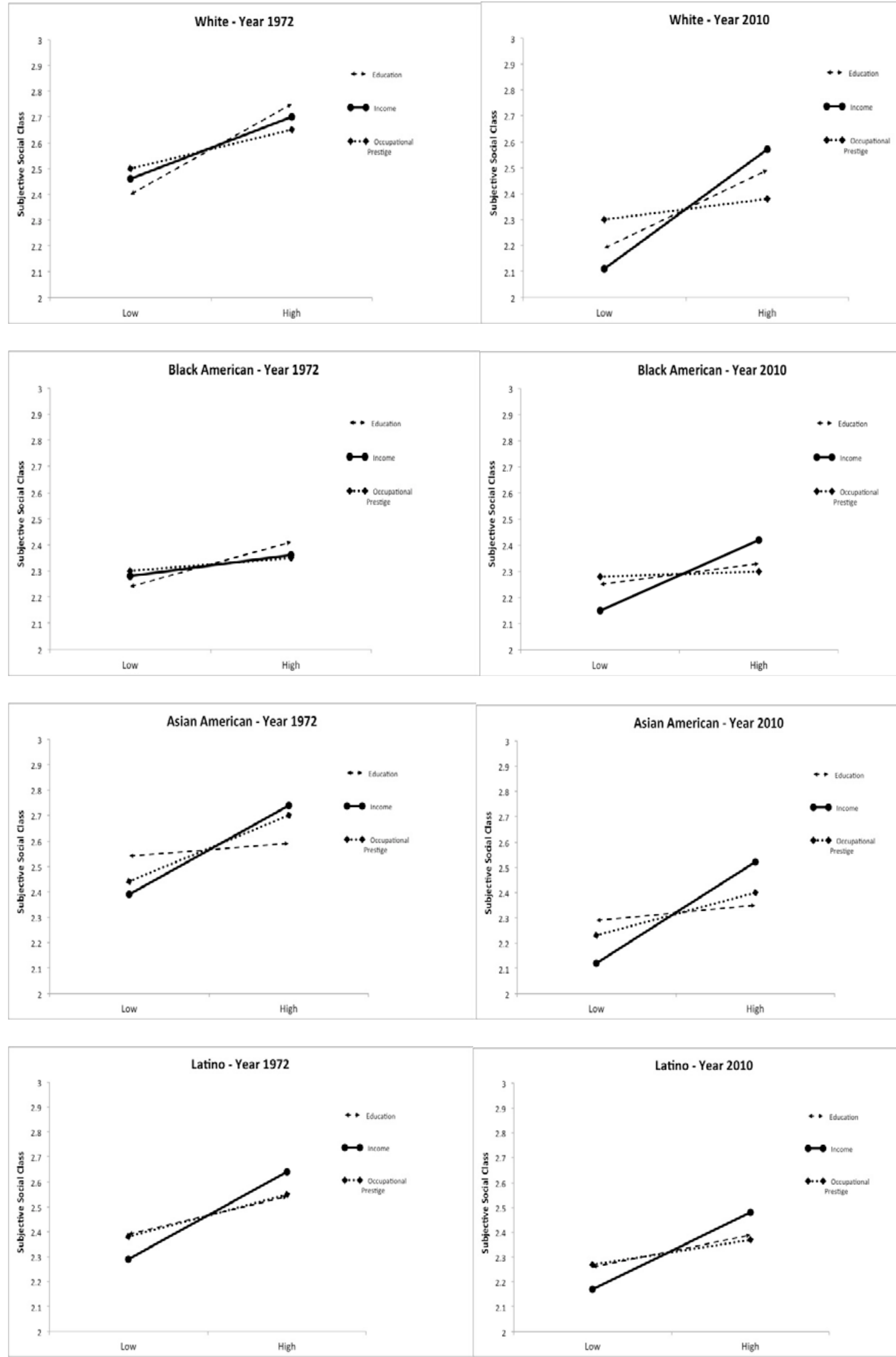
Figure 1. Predicted values for subjective social class as a function of education, income, and occupational prestige for 4 ethnic groups in 1972 and 2010.

\section{Race and caste-as-class: Change, continuity, and consequences for poor White and Black} Americans.

Figure 2 shows the diminishing effects of ethnicity over time in terms of absolute levels of subjective class. After controlling for “objective” differences in income, education, and occupational prestige, the gap between White respondents' subjective class and that of Latino and Black respondents became significantly smaller over the past four decades. (As shown in

Table 1 , the year $\times$ Latino and year $\times$ Black interaction terms were significant. The year $\times$ Asian American interaction was not). In 1972, Whites’ subjective class was higher than that of Latinos and all groups were higher than that of Black respondents. By 2010, the only significant difference between any of the ethnicities was that between White and Black Americans; but that difference was a fraction of its former self (predicted value of b for the Black dummy was -0.05 in 2010 vs. -0.25 in 1972 , both $p s \leq 0.002$ ), and the closing of the gap was due almost entirely to the drop among Whites (Figure 2). The increasing significance of money for Whites is consistent with this finding about the diminishing boost from Whites’ ethnicity per se: Whites’ subjective class came to depend less on ethnicity, more on money. 


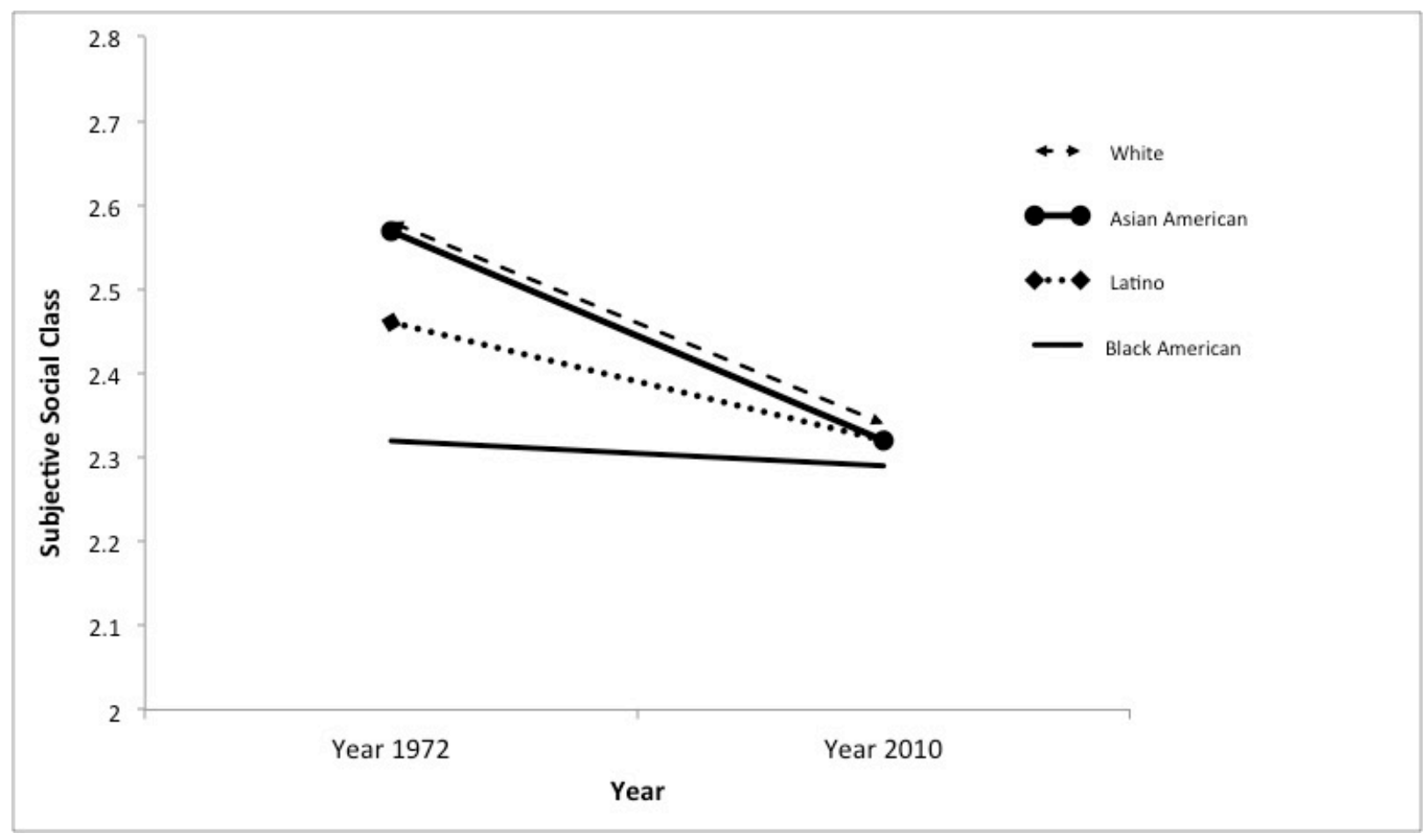

Figure 2. Predicted value of subjective social class for 4 ethnic groups over time.

Consequences for poor Whites' subjective sense of class were particularly striking. As of 1972, poor Whites still had an enhanced sense of their social class, compared to other poor people (and compared to poor Whites in 2010). Thus, the predicted subjective class value for those $1 S D$ below the mean in income in 1972 was 2.46 for Whites -- a value significantly higher than that for Latino (2.29) and Black Americans (2.28) ( $p s<0.001$ for Latino and Black dummy variables with income centered at 1 SD below the mean and year centered at the 1972 value), though it was not significantly different from that for Asian Americans (2.39). In fact, in 1972, the predicted value for poor Whites' subjective class (95\% CI[2.44, 2.47]) was even higher than the predicted value of subjective class for rich Black Americans (predicted value of 2.36 (95\% $\mathrm{CI}[2.30,2.42])$ for Blacks $1 \mathrm{SD}$ above the mean in income), though not rich Latinos (2.64) or rich Asian Americans (2.74). By 2010, however, any subjective sense of enhanced class status among poor Whites was gone. For 2010, the predicted value for poor Whites was slightly but 
significantly lower than that for poor Latino and Black Americans $(p=0.043$ and $p=0.0498$ for Latino and Black dummy variables when year was centered at 2010 and income centered at 1 SD below the mean; $\mathrm{p}=0.01$ and $\mathrm{p}=0.001$ for those Latino and Black dummy variables with income centered at 1.5 SD below the mean. Predicted values for Whites, Latinos, Blacks at 1 SD below=2.11, 2.17, 2.15, respectively; at $1.5 \mathrm{SD}$ below=1.99, 2.09, 2.08; see Figure 3 panels a and b).

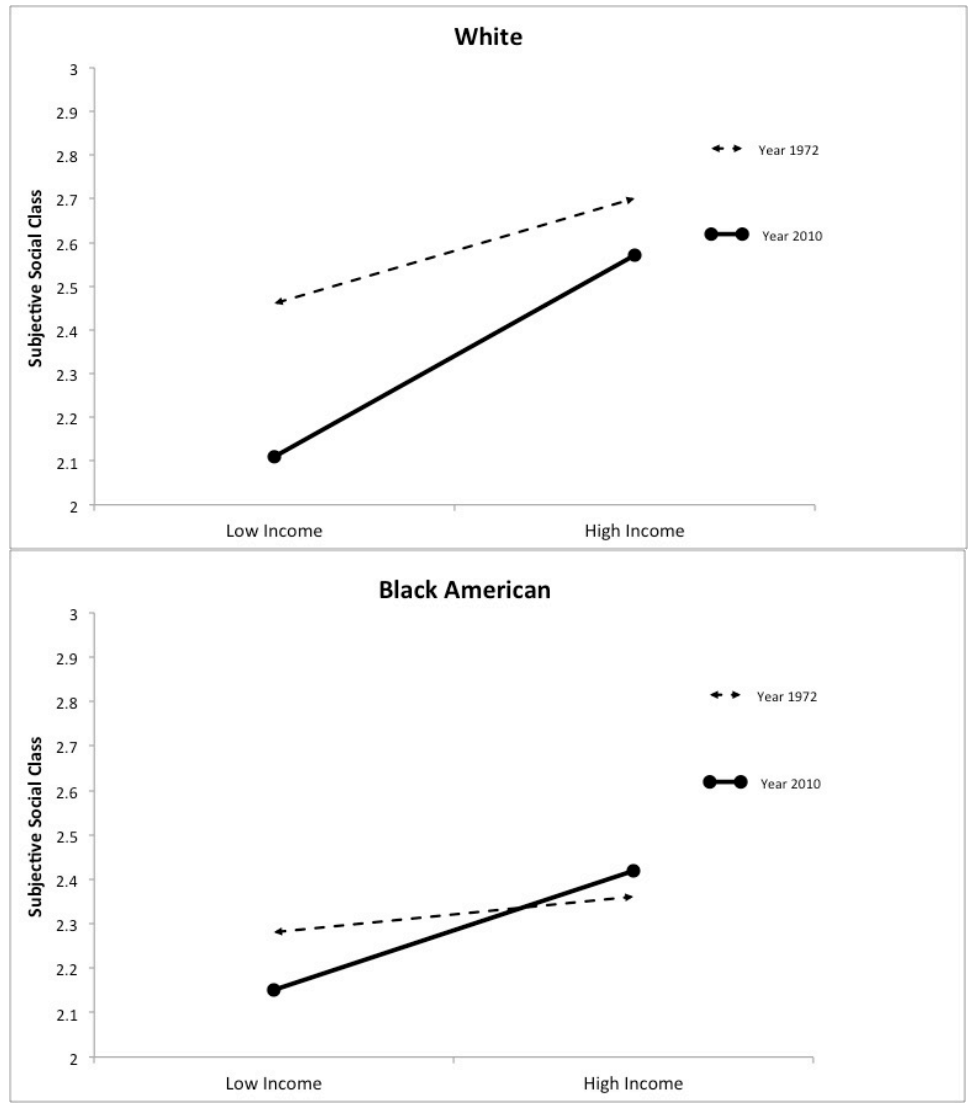

Figure 3. Predicted values for subjective social class among high and low income White and Black Americans in 1972 and 2010.

However, just because Whites no longer derived as much caste-like benefit from their whiteness in terms of subjective status, this did not mean that Black respondents no longer felt that their status position was caste-like. First, as seen in Figure 2, most of the closing of the gap 
between White and Black Americans was due to the "net” decline among Whites over time. And as seen in Figure 1, Black respondents believed (1972) and continued to believe (2010) that their subjective social class was relatively less dependent on objective measures such as income, education, and occupational prestige, as compared to people of other groups. Latinos and Asian Americans are similar to Whites in the way they conceive of social class as defined by their achieved income and occupational prestige. Black Americans are not.

Even in the case of income, which has increased in importance for Black respondents over the past four decades, the relationship between income and subjective class among Black respondents is flatter than it is among Whites. Because the line relating income and subjective class has gotten so much steeper for Whites over these past four decades, income continues to under-predict subjective class for Black respondents relative to Whites in 2010 just as much as it did in $1972($ Year $\times$ Black $\times$ Income interaction $p=0.67)$.

Interactions of ethnicity with prestige and with education over time. Interactions of ethnicity $\times$ prestige $\times$ year and ethnicity $\times$ education $\times$ year were not significant for any of our ethnicity dummy variables. Regarding education, however, this was the one example where Whites did not resemble Latinos or Asian Americans, as education had greater effects for Whites as compared to all other groups ( $p s<0.001)$. Why education would matter more for Whites than for other groups is an open question. ${ }^{4}$

\footnotetext{
${ }^{4}$ It is possible the independent effect of education is more important for Whites than for other groups, because the effect of education is more indirect for Black, Latino, and Asian Americans, operating through effects on prestige and income. The data do not support this conjecture. As a zero-order correlation, education is equally correlated with a 2-item index of prestige and income for White $(r=0.59)$ and Black respondents $(r=0.57)$. Education's correlation with the two-item index is slightly lower for Latinos $(r=0.53)$ and Asian Americans $(r=0.52)$. These correlations imply that, all else equal, we would expect the independent effect of education to be smaller for Whites, not larger. Also, the zero-order correlation between education and subjective class was
} 


\section{The "Victorian bargain"}

Finally, the expected interaction of conventional morality $\times$ income was significant. However, it was in turn moderated by year (year $\times$ conventional morality $\times$ income interaction $p=0.001$ ). As seen in the left panels of Figure 4, in 1972, subscribing to conventional values of religiosity and restricted sexuality went some way toward giving a poor person a sense of middle-class status. Among Black respondents, a poor person (-1 SD in income) who subscribed to such values viewed him/herself as just as middle-class as a rich person (+1 SD in income). Among poor Whites and Asians, subscribing to such values also went a considerable way toward closing the status gap with their richer counterparts. The only group for which this did not hold was Latinos. By 2010, however, the "Victorian bargain” was gone (right panels of Figure 4). (The significant year $\times$ morality $\times$ income interaction was not moderated by any ethnicity variable. The exception was the Latino dummy variable, because the "Victorian bargain" never held for them in 1972; Latino $\times$ year $\times$ morality $\times$ income interaction $p=0.037$ ).

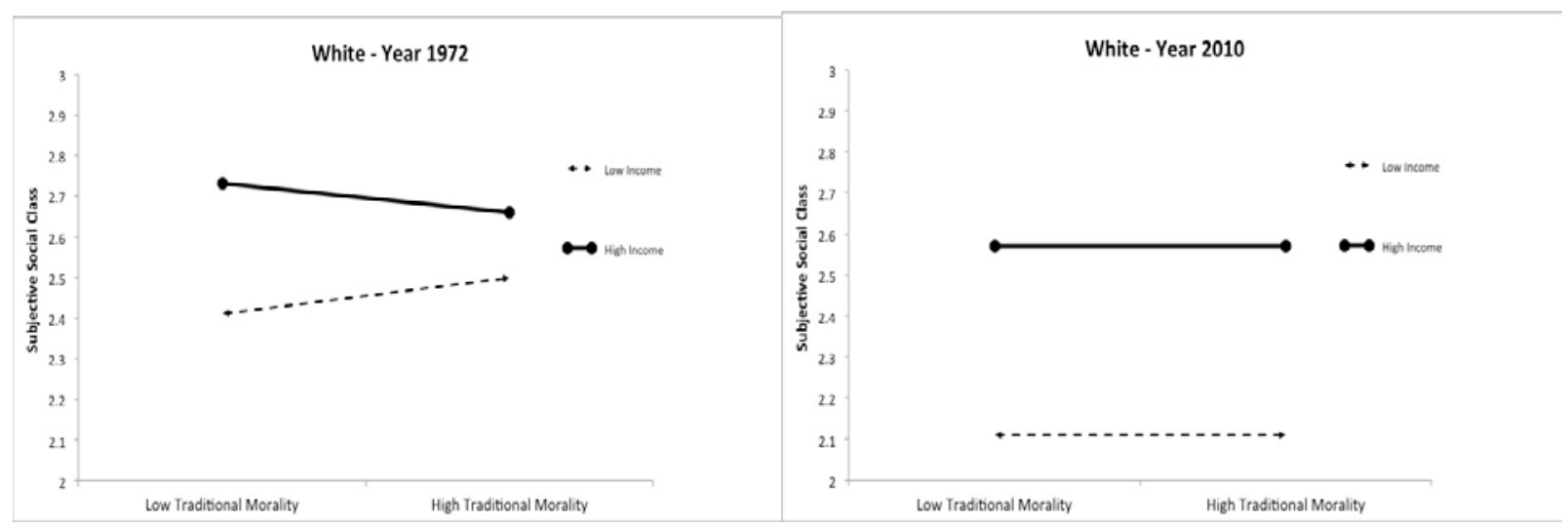

$r=0.33$ for Whites and was significantly lower for Asian $(r=0.25)$, Latino $(r=0.22)$, and Black Americans ( $r=0.11)$. 

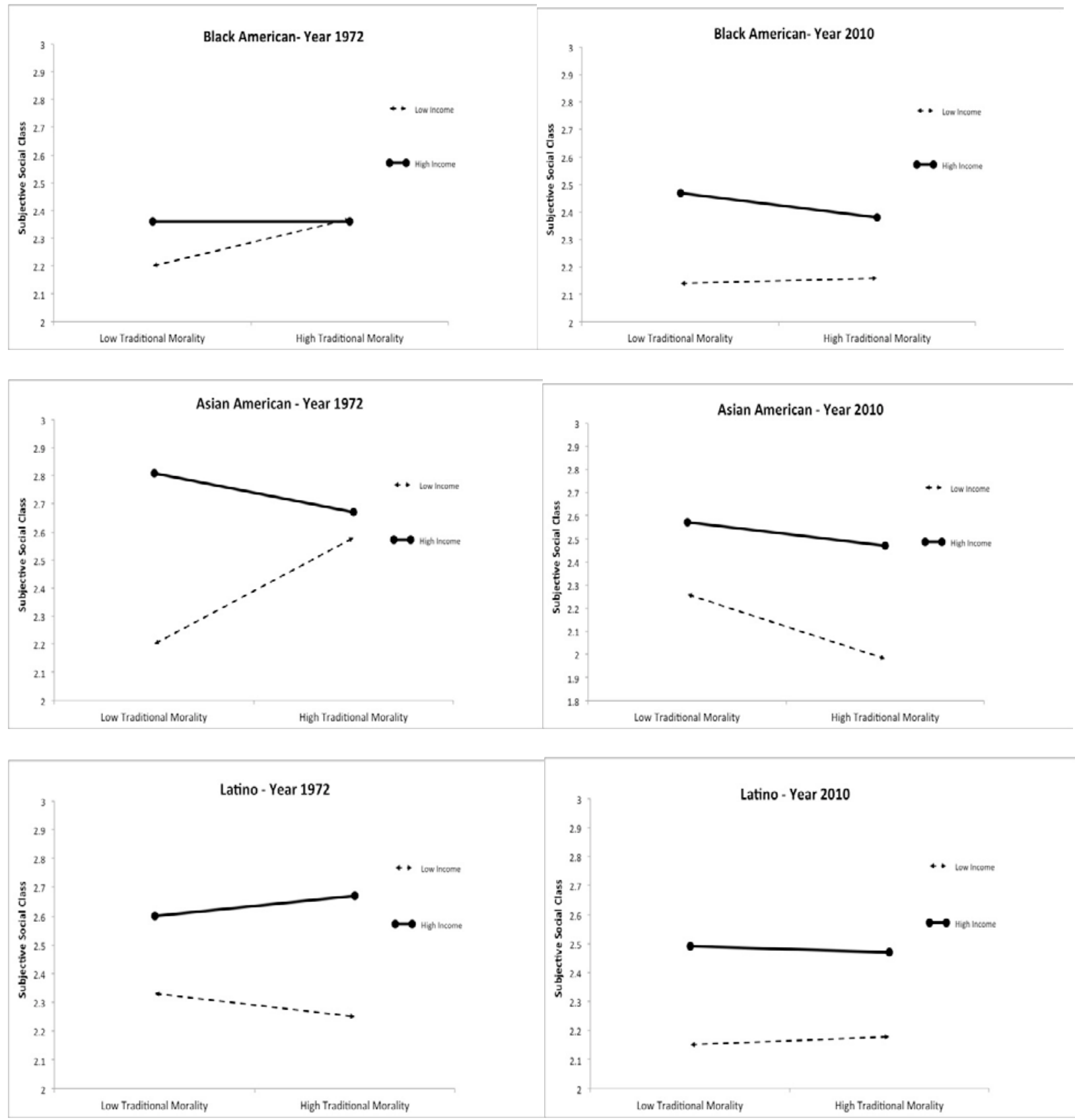

Figure 4. Predicted values for subjective social class as a function of income and traditional morality for 4 ethnic groups in 1972 and 2010.

\section{Subjective class among Black Americans: Soft vs. hard indicators.}

Early research contrasting Black and White Americans (Jackman \& Jackman, 1973), as well as results above, suggest that Black Americans stand out in terms of objective indicators 
having relatively slight effects on their subjective social class. Some scholars have suggested that “class” in Black communities is defined by factors that go beyond money and occupation (Hunt \& Ray, 2012). Such factors include family background, contribution to the community, marital status, wealth, neighborhood, and so on. With some exceptions, the GSS questions are not ideally suited to measure such variables. Nevertheless, we looked to see if there were some variables close to the constructs of interest. A plausible hypothesis - given the importance of community solidarity and giving back to others in the Black community -- is that class is at least partially defined by commitment to the group and to helping others (Brannon, Markus, \& Taylor, 2015; Cokley, 2005; Lamont, 2002; Oyserman, Gant \& Ager, 1995). We examined this by looking at participants’ activities and membership in voluntary organizations that build social capital or are directly aimed at community betterment. We examined family background by looking at available “objective” indicators of parents’ socio-economic status (an index of parents' education, parents' occupational prestige, and family income when respondents were 16-years-old). We also examined church membership separately, given the prominent role the church plays in the Black community. We examined marital status, home ownership, and how the respondent's residence compared to others in the neighborhood and in the city. Table 2 shows partial r's (controlling for income, education, and occupational prestige) between these variables and subjective class for the four ethnic groups (along with $n$ s for each item).

Table 2. Partial correlation of variables with subjective social class within each ethnic group. (Partial correlations control for income, education, and occupational prestige).

$\begin{array}{cccc}\text { White } & \text { Black } & \text { Latino } & \text { Asian } \\ \text { Respondents } & \text { Respondents } & \begin{array}{c}\text { American } \\ \text { Respondents } \\ \text { Respondents }\end{array}\end{array}$

\begin{tabular}{lcccc}
\hline $\begin{array}{l}\text { Community } \\
\text { work/voluntary } \\
\text { organizations }\end{array}$ & $0.05 *$ & $0.06 *$ & $0.07 *$ & 0.00 \\
\hline
\end{tabular}




\begin{tabular}{|c|c|c|c|c|}
\hline $\begin{array}{l}\text { Church membership in } \\
\text { particular }\end{array}$ & $\begin{array}{c}0.07 * \\
(15271)\end{array}$ & $\begin{array}{l}0.05 * \\
(2423)\end{array}$ & $\begin{array}{l}0.05 \\
(831)\end{array}$ & $\begin{array}{l}-0.03 \\
(187)\end{array}$ \\
\hline Parent SES & $\begin{array}{c}0.09 * \\
(36260)\end{array}$ & $\begin{array}{l}0.08 * \\
(6269)\end{array}$ & $\begin{array}{l}0.08 * \\
(2767)\end{array}$ & $\begin{array}{l}0.06 \dagger \\
(738)\end{array}$ \\
\hline Own house & $\begin{array}{l}0.08 * \\
(15707)\end{array}$ & $\begin{array}{l}0.08 * \\
(2965)\end{array}$ & $\begin{array}{l}0.05 \dagger \\
(1351)\end{array}$ & $\begin{array}{l}0.07 \\
(396)\end{array}$ \\
\hline Wealth estimate & $\begin{array}{l}0.19 * \\
(1032)\end{array}$ & $\begin{array}{l}0.01 \\
(193)\end{array}$ & $\begin{array}{l}0.27 * \\
(114)\end{array}$ & $\begin{array}{l}-0.02 \\
(40)\end{array}$ \\
\hline $\begin{array}{l}\text { House relative to the } \\
\text { neighborhood }\end{array}$ & $\begin{array}{l}0.11 * \\
(3055)\end{array}$ & $\begin{array}{l}0.01 \\
(726)\end{array}$ & $\begin{array}{l}0.02 \\
(136)\end{array}$ & $\begin{array}{l}0.08 \\
(33)\end{array}$ \\
\hline House relative to the city & $\begin{array}{l}0.14 * \\
(3037)\end{array}$ & $\begin{array}{l}0.03 \\
(720)\end{array}$ & $\begin{array}{l}0.22 * \\
(136)\end{array}$ & $\begin{array}{l}0.26 \\
(33)\end{array}$ \\
\hline Currently married & $\begin{array}{l}-0.05 * \\
(36260)\end{array}$ & $\begin{array}{c}0.02 \\
(6269)\end{array}$ & $\begin{array}{c}-0.01 \\
(2767)\end{array}$ & $\begin{array}{l}0.04 \\
(738)\end{array}$ \\
\hline Ever married & $\begin{array}{c}0.00 \\
(36260)\end{array}$ & $\begin{array}{c}0.01 \\
(6269)\end{array}$ & $\begin{array}{l}-0.01 \\
(2767)\end{array}$ & $\begin{array}{l}0.01 \\
(738)\end{array}$ \\
\hline Divorced & $\begin{array}{c}-0.06^{*} \\
(36260)\end{array}$ & $\begin{array}{l}-0.03^{*} \\
(6269)\end{array}$ & $\begin{array}{c}0.00 \\
(2767)\end{array}$ & $\begin{array}{l}-0.03 \\
(738)\end{array}$ \\
\hline
\end{tabular}

Notes: $* p \leq 0.05$, two tailed. $\dagger p \leq 0.10$, two tailed. Sample size is in parentheses.

As shown, community work and volunteerism, church membership, parental SES, and homeownership all mattered to Black respondents - and did so to about the same degree for respondents of other groups. Surprisingly, wealth did not predict subjective class for Black respondents, as it did for White and Latino respondents. Even the zero-order correlation between wealth and subjective class was surprisingly weak for Black $(r=0.10, p=0.16)$ as compared to White ( $r=0.36, p=0.001)$, Latino $(r=0.40, p=0.001)$, and Asian Americans $(r=0.25, p=0.09)$. Further, the interviewer's rating of the respondent's residence compared to others in the city also did not predict subjective class for Black respondents as it did for other groups. Admittedly, 
wealth and residence were crudely measured, but their lack of relationship to Black respondents' subjective class is consistent with the view that material wealth matters less for Black Americans' sense of social class, as compared to how much it matters for other groups.

Thus, Black respondents' subjective class is predictable, but it does not give nearly the weight to “objective” economic indicators that matter so much for Whites, Latinos, and Asian Americans. Because sample sizes drastically shrink when we include variables from Table 2, we hesitate to add too many variables to the model. Yet it is instructive to run analyses for the four groups separately (Ostrove et al., 2000), using only the three “objective” SES indicators (income, education, and prestige) and the three “soft” indicators (values, community work, and family background). Adding up the $b$ values for the standardized independent variables, we find that for Whites, the $b$ values for the objective indicators total 0.32 , whereas the soft indicators total 0.12 ; for Latinos, the $b$ s for objective indicators total 0.25 , whereas the soft indicators total 0.10 ; for Asians, the $b$ s for objective indicators total 0.33, whereas the soft indicators total 0.09; for Black respondents, the $b$ s for objective indicators total 0.11 , whereas the soft indicators total 0.15 . Thus, unlike for the other groups, Black respondents’ subjective class depends slightly more on these "soft” indicators than on so-called “objective” indicators. For Asians, Latinos, and Whites, objective indicators are 2.5-3 times more important than these soft indicators.

\section{What the data do not indicate: Subjective class vs. self-worth}

It is important to clarify what these results do not say. A sense of social class within the larger American society is, of course, theoretically distinct from self-esteem, how one feels about oneself. African-Americans, for example, may perceive they have lower social class than Whites given the same levels of income, education, and occupational prestige - but Black Americans have had higher self-esteem than Whites for the past three decades (Twenge \& Crocker, 2002). 
Further, relations between objective indicators of achievement, self-esteem, and subjective class are different among ethnic groups in the current data.

Objective achievement indicators and self-esteem. A 3-item achievement index of income, education, and occupational prestige predicts self-esteem to the greatest degree among Black respondents $(r=0.34, p=0.001, n=306)$, but less so for Whites $(r=0.21, p=0.001, n=1756)$, Latinos ( $r=0.19, p=0.01, n=214)$, and Asian Americans ( $r=-0.09$, ns, $n=77)$. Thus, "objective” achievement is quite important for Black respondents’ self-esteem - and in fact such achievement is significantly more important for Black Americans' self-esteem than it is for any other group (Zs for the difference in correlations: Black vs. White $Z=2.25, \mathrm{p}=0.024$; Black vs. Latino Z=1.81, $\mathrm{p}=0.072$; Black vs. Asian American $\mathrm{Z}=3.39, \mathrm{p}=0.001$ ). This is further evidence against the “oppositional” hypothesis that there is a broad disengagement from mainstream achievement among Black Americans (cf. Fordham \& Ogbu, 1986, on an “oppositional” stance to school achievement; also Ainsworth-Darnell \& Downey, 1998).

In the present data, the only thing Black respondents have dissociated from mainstream achievement is their subjective perception of social class. And this result should not be too surprising: if members of a group know they are in a stigmatizing environment, they may separate feelings of self-worth derived from achievement from feelings of social worth within the larger society (Crocker et al., 1998).

In sum, achievement as indicated by income, education, and occupational prestige predicts self-esteem to a greater degree among Black, as compared to White and Asian Americans. And among Black respondents, the achievement index correlates with their selfesteem more than it does with their subjective class. In contrast, for Whites, Asian Americans, 
and Latinos, achievement correlates more with their subjective class than it does with their selfesteem ${ }^{5}$.

Subjective class and self-esteem. Finally, self-esteem correlates with subjective class only for White ( $r=0.24, p=0.001)$, not for Black $(r=0.03$, ns), Latino $(r=0.05$, ns), or Asian Americans ( $r=-0.05$, ns); and this distinction remains even when one partials out objective class variables (partial $\mathrm{r}$ between subjective class and self-esteem for White $=0.17, \mathrm{p}=0.001$; Black=0.02, ns; Latino=-0.01, ns; Asian Americans=-0.02, ns). This finding makes sense if Whites see themselves as in the mainstream of American society and define themselves by their place within this larger category (as opposed to more collectivist groups in which people define themselves in terms of smaller ingroups, close kin, or other relevant communities (Triandis, 1994; Yuki, 2003)).

\section{Discussion}

With psychology’s resurgent interest in class, researchers have shown how subjective class is important to a number of outcomes including well-being and health, attention to self vs. other, and social and political attitudes (Kraus et al., 2012). The present paper has examined the way this subjective sense of class has been constructed differently across time and across different groups.

\footnotetext{
${ }^{5}$ Correlations between the index of achievement and self-esteem are in the text. For comparison, correlations between the index and subjective social class were 0.41 for Whites, 0.30 for Latinos, 0.39 for Asian, and 0.15 for Black Americans. The correlation between the index and subjective social class was significantly bigger than the correlation between the index and self-esteem for Whites (Z-score for the difference in correlations $=8.93, p=0.001)$, Asian Americans $(Z=4.14$, $p=0.001)$, and Latinos (marginally) $(Z=1.70, p=0.09)$. The pattern was reversed among Black respondents $(Z=-3.44, p=0.001)$.
} 
People from all groups during the period we examined defined their social class partially by objective indicators, such as income, education, and occupational prestige. Beyond this, however, results showed that:

a) Over time, income surpassed education and became the most important predictor of subjective class in the GSS data. During the period under study, wages for the median worker stagnated, debt loads increased, the gap between high- and low-income workers spread, and job security became more tenuous. These factors plausibly explain the rising importance of income; but, of course, many other changes also occurred between 1972 and 2010, and our correlational data do not allow safe causal inferences. Over the four decades, occupational prestige also decreased as a determinant of subjective class.

b) Ethnicity became less important as a predictor of subjective class. Controlling for income, education, and occupational prestige, Whites’, Asian Americans’, and Latinos’ subjective class dropped closer to the level Black respondents reported in 1972 (and continued to report in 2010). Combined with the increasing importance of income, the decreasing importance of ethnicity had the greatest effect on poor Whites, who formerly reported substantially higher subjective class than poor Black and Latino respondents but who now report slightly lower.

c) For Black respondents, a caste-like understanding of social class has persisted. “Objective” indicators (income and occupational prestige) are strong predictors of subjective class for Whites, Asian Americans, and Latinos. However, they are much weaker predictors for Black Americans, consistent with the notion that Black Americans believe their social standing is relatively independent of their achieved income, occupational prestige, and education.

The gap between White and Black Americans -- in terms of how much their subjective status depends on income, education, and occupational prestige -- has not closed significantly 
over the past four decades. Even wealth seems to have little effect on Black respondents' sense of subjective class. Wealth was only asked about in one year (2006), but its partial correlation with subjective class was an insignificant $r=0.01$ for Black respondents. In general, it seems as if Whites no longer report higher subjective class as a function of their favored racial status, whereas Black Americans still think of their social class in moderately caste-like terms, with their status being relatively independent of achievement indicators.

d) Over the past four decades, the "Victorian bargain” has disappeared. In earlier periods, poor people who might not “qualify" for middle-class status by dint of income might qualify for middle-class status by dint of the values they embraced. By 2010, however, the Victorian bargain was gone, as traditional morality - at least as measured by the questions we used -- no longer had much effect on subjective class and could no longer bridge the subjective status gap between rich and poor.

e) For unknown reasons, education influenced subjective class for Whites more than for others.

f) Black respondents (and people of other groups) defined their subjective class partly by soft indicators such as community involvement and family background. Combined with results from point (c), this meant that Black Americans defined class slightly more by these soft indicators than by “objective” indicators. For all other groups, objective indicators were approximately three times more important than the soft indicators we examined.

g) Objective indicators of achievement did correlate with Black respondents’ selfesteem. Indeed, among Black Americans, a 3-item achievement index was correlated $r=0.34$ with self-esteem - a correlation higher than that for any other group. Thus, achievements in income, education, and occupational prestige are clearly important for Black Americans’ understanding 
of themselves; such achievements just do not much affect Blacks Americans’ sense of their class position within the larger society.

h) Only among Whites was subjective class correlated with self-esteem. This may be because Whites see themselves as in the mainstream of American society and are least likely to define themselves in terms of smaller ingroups. Among other ethnicities, a person's social standing in the larger society may be less important than their standing among close kin, ingroup members, or more defined communities. This reasoning is speculative, however, and the causal direction is unclear.

\section{Caveats}

There are many caveats to this research. It is correlational rather than experimental. The sample size for some groups (such as Asians and Latinos) was relatively small by national survey standards, particularly for early years of the survey or for questions not asked repeatedly. We examined linear trends over time, thus giving short-shrift to any potential nonlinear trends. The questions we analyzed -- particularly as related to values and other soft indicators of social class - may have been off-target. And so on.

There is, however, one major caveat that we want to particularly draw attention to. We noted that some of the data are consistent with Black Americans seeing their social class in castelike terms, reflecting the long history of racism in America. However, there is another possible explanation to explore for why objective indicators underpredict Black respondents’ subjective class. That is, it is possible that the "objective” indicators are missing some crucial "hidden information.” Thus, a Black and a White respondent may have the same years of education, but the White respondent may have gone to a more prestigious school. They may have the same 
income or occupation but the White may have more wealth, a more secure job, or may be selfemployed (Cohen, Shin, \& Liu, 2017; Thompson \& Suarez, 2015). And so on.

These are very plausible explanations and likely account for part of the effect. However, when we were able to at least partially test these explanations, they ultimately came up short. More specifically: 1) we can control for whether the respondent worked for him- or herself as well as for the respondent's perceived job security, and doing so does not change the results; 2) when we examined a crude measure of wealth, wealth predicted subjective status for Latinos and Whites, but not for Black Americans, consistent with Black respondents regarding their status position as relatively independent of money; 3) if "hidden information” about the respondent were responsible for underpredicting Black respondents’ social class, “hidden information” about the respondent's parents (occupation, income, education) should likely do so as well. However, it does not; partial correlations involving family background were similar across all four groups.

We do believe that "hidden information" likely accounts for some of why income, education, and occupational prestige under-predict subjective class for Black Americans. However, in trying to get a handle on how much it might account for, we were unable to turn up any evidence that it mattered at all. The safest conclusion may be that "hidden information" likely has some effect; but it is unlikely to fully explain the observed pattern, from which it seems plausible to infer that Black respondents show some tendency to view their status in more caste-like terms. ${ }^{6}$

\footnotetext{
${ }^{6}$ The tendency for income to underpredict subjective class for Black respondents occurs despite some factors that should lead income to underpredict for Whites. First, income segregation is lower among Whites than among Black Americans (Reardon \& Bischoff, 2011; Wilson, 1990), which should make income relatively less important for Whites. Second, wealth gaps between White and Black Americans are on the order of approximately 10-to-1 (Thompson \& Suarez,
} 


\section{Implications}

White status loss and Black marginalization. The findings suggest a number of implications. For example, Whites not only see their numerical status as a majority disappearing (Craig \& Richeson, 2014a); but particularly for poor Whites, their enhanced sense of class status simply for being White has disappeared as well. Potential implications of this status loss for Whites’ political attitudes (including working-class Whites’ shift toward conservatism and Trump-ism), their perceptions of reverse racism, sense of economic insecurity, increasing rates of mid-life mortality due to self-inflicted causes (particularly pronounced among those with a high school degree or less), and their nostalgia for a bygone America -- as well as the effects on intergroup relations generally (Fein \& Spencer, 1997) -- seem worth studying.

Among Black respondents, the persistence of a caste-like assessment of their social status suggests a sense of marginalization that has not changed much over 40 years and that sets them apart from their Latino, Asian American, and White peers. Implications of this for a variety of social, political, and psychological phenomena - as well as for the "Black exceptionalism” hypothesis - seem worth exploring.

Methodology. Results also have wider methodological and interpretive implications for those who either study or want to "control for” social class. Data on objective indicators of class can sometimes be difficult to come by. Whereas it may be easy to ask about education, respondents are sometimes reluctant to reveal their income, regarding it as sensitive information. Researchers also need a fair amount of expertise to classify respondents’ occupations with some specificity. Wealth estimates can have quite a bit of error and are often idiosyncratic. Thus, it is far easier to ask someone about their subjective class than about objective characteristics. But,

2015). The greater wealth of Whites should make income less crucial to their self-defined social class. 
the problem is that when we ask about subjective class, we may be getting different things when we ask people from different ethnic groups. If subjective class predicts our dependent measures better for Whites, Latinos, and Asian Americans (as compared to Black respondents), is this just because subjective class tracks objective measures better for these non-Black groups? For example, subjective class is correlated about .15 with self-reported health for all groups - except Black Americans, for whom the relationship is half as large $(r=0.07)$. However, this is not because social class matters less for Black Americans. It is only because subjective class tracks objective indicators much more poorly for Black Americans than for other groups. (For all groups, the correlation between objective class indicators and self-reported health is about 0.30 ; Supplementary Materials). In still other cases, subjective class may predict an outcome equivalently across groups, but the correlation could be driven by “objective” indicators among non-Blacks and “soft” indicators (values, family background, community participation) among Black Americans.

Conversely, to the extent that our theoretical construct of interest is not material resources but people's psychological sense of their own status in society, we can map income and job data onto respondents’ psychological sense with much greater accuracy for White, Latino, and Asian Americans than for Black Americans. In such research, particularly for Black respondents, it will be important to explicitly ask about subjective social class rather than infer it from objective indicators. Relatedly, when we attempt to gauge subjective class by categorizing people according to education, is this a more appropriate criterion for Whites than for other groups? If so, explicitly asking respondents, particularly non-Whites, about subjective class may be more prudent than relying on education, job, or income data alone (see also Rubin et al., 2014). 


\section{Conclusion}

With psychologists rediscovering the importance of class for a number of different outcomes, it is important to note the considerable variation across time and across groups in how one’s subjective social class is constructed. Whether people understand class as involving certain moral codes, whether it is primarily a matter of money (as opposed to occupation or education), whether education even matters except as it allows access to jobs and money, whether race operates in a caste-like fashion to trump objective achievements, whether objective achievements matter for self-esteem even when they do not matter for subjective class (and vice versa), and whether our self-esteem is correlated with our estimates of our social standing in the larger society - these are likely just a slice of a larger set of issues concerning how social class is constructed differently across time and across peoples. Social class is a concept that often seems difficult to define and is multi-faceted. This is true for psychologists, in part, because of the diverse conceptions of social class that the public holds as well. 


\section{References}

Adler, N. E., Epel, E. S., Castellazzo, G., \& Ickovics, J. R. (2000). Relationship of subjective and objective social class with psychological functioning. Health Psychology, 19, 586-592.

Boyer, P. (1978). Urban masses and moral order in the United States. Cambridge: Harvard.

Brannon, T.N., Markus, H.R., \& Taylor, V.J. (2015). “Two souls, two thoughts,” two selfschemas. Journal of Personality and Social Psychology, 108, 586-609.

Brown-Iannuzzi, J., Lundberg, K.B., Kay, A.C., \& Payne, K. (2015). Subjective status shapes political preferences. Psychological Science, 26(1), 15-26.

Case, A., \& Deaton, A. (2015). Rising morbidity and mortality in midlife among white nonHispanic Americans in the 21st century. Proceedings of the National Academy of Sciences, 112(49), 15078-15083.

Clark, K.B., \& Clark, M.P. (1947). Racial identification and preference in Negro children. In T. Newcomb \& E. Hartley (Eds.), Readings in social psychology. NY: Holt.

Cohen, A. \& Varnum, M. (2016). Beyond East vs. West. Current Opinion in Psychology, 8, 5-9.

Cohen, D., Shin, F., \& Liu, X. (2017). The cultural psychology of money. To appear in D. Cohen \& S. Kitayama (eds) Handbook of Cultural Psychology ( $2^{\text {nd }}$ edition). NY: Guilford.

Craig, M.A., \& Richeson, J.A. (2014a). More diverse yet less tolerant? Personality and Social Psychology Bulletin, 40, 750-761.

Crocker, J., Major, B., \& Steele, C. (1998). Social stigma. In D. Gilbert, S. Fiske, \& G. Lindzey (eds). Handbook of Social Psychology (pp. 504-553). NY: McGraw-Hill.

Duncan, B. \& Trejo, S. (2016). The complexity of immigrant generations. NBER Working Paper 21982. 
Fein, S. \& Spencer, S. (1997). Prejudice as self-image maintenance. Journal of Personality and Social Psychology, 73, 31-44.

Fiske, S.T., \& Markus, H.R. (Eds.) (2012). Facing social class. NY: Russell Sage.

Frank, R. (1985). Choosing the right pond. NY: Oxford.

Grossman, I. \& Varnum, M. (2015). Social structure, infectious diseases, disasters, secularism, and cultural change in America. Psychological Science, 26, 311-324.

Gusfield, J. (1986). Symbolic crusade. Champaign: University of Illinois Press.

Hout, M. (2004). Getting the most out of the GSS income measures. Chicago: NORC.

Hout, M. (2008). How class works. In A. Lareau \& D. Conley (Eds.), Social class (pp. 25-64). NY: Russell Sage.

Hunt, M.O., \& Ray, R. (2012). Social class identification among Black Americans. American Behavioral Scientist, 56(11), 1462-1480.

Hyslop-Margison, E. (2008). Middle class morality. In F.C. Power (ed). Moral education (pp. 267-270). Westport: Greenwood.

Jackman, M. and Jackman, R. (1973). An interpretation of the relation between objective and subjective social status. American Sociological Review, 38, 569-82.

Kraus, M.W., Piff, P.K., \& Keltner, D. (2009). Social class, sense of control, and social explanation. Journal of Personality and Social Psychology, 97, 992-1004.

Kraus, M.W. et al. (2012). Social class, solipsism, and contextualism. Psychological Review, 119, 546-572.

Lamont, M. (2002). The dignity of working men. Cambridge: Harvard.

Lazear, E. \& Shaw, K. (2007). Personnel economics. Journal of Economic Perspectives, 21, 91114. 
Lazear, E. \& Shaw, K. (2008). Wage structure, raises, and mobility. In E. Lazear \& K. Shaw (eds). The structure of wages. Chicago: Chicago.

Leicht, K. (2012). Borrowing to the brink. In K. Porter (Ed.), Broke. Stanford: Stanford.

Liu, W.M., Ali, S.R., Soleck, G., Hopps, J., \& Pickett Jr, T. (2004). Using social class in counseling psychology research. Journal of Counseling Psychology, 51(1), 3.

Mahalingam, R. (2003). Essentialism, culture, and power. Journal of Social Issues, 59, 733-49.

Marglin, S. \& Schor, J. (1990). The golden age of capitalism. Oxford: Clarendon.

Massey, D., Rothwell, J., \& Domina, T. (2009). The Changing Bases of Segregation in the United States. American Academy of Political and Social Science, 626, 74-90.

Murrin, J., Hamalainen, P., Johnson, P., Brunson, D., \& McPherson, J. (2015). Liberty, equality, power. NY: Cengage.

Norton, M. \& Sommers, S. (2011). Whites see racism as a zero-sum game that they are now losing. Perspectives on Psychological Science, 6, 215-218.

Osterman, P. (2014). Securing prosperity. Princeton: Princeton.

Ostrove, J., Adler, N., Kuppermann, M., \& Washington, A.E. (2000). Objective and subjective assessments of socioeconomic status and their relationship to self-rated health in an ethnically diverse sample of pregnant women. Health Psychology, 19, 613-618.

Oyserman, D., Gant, L., \& Ager, J. (1995). A socially contextualized model of African American Identity. Journal of Personality and Social Psychology, 69, 1216-1232.

Pew. (2015). A deep dive into party affiliation. Washington: Pew.

Piketty, T. (2014). Capital in the Twenty-first Century. Cambridge: Harvard.

Rajan, R. \& Wulf, J. (2006). The flattening firm. Review of Economics and Statistics, 88, 759773. 
Reardon, S. (2011). The widening academic achievement gap between rich and poor. In G. Duncan \& R. Murnane (eds). Whither opportunity (pp. 91-116). NY: Russell Sage.

Reardon, S. \& Bischoff, K. (2011). Income inequality and income segregation. American Journal of Sociology, 116, 1092-1153.

Reich, R. (2016). Saving capitalism. NY: Vintage.

Richeson, J.A., \& Sommers, S.R. (2016). Toward a social psychology of race and race relations for the twenty-first century. Annual review of psychology, 67, 439-463.

Rubin, M. et al. (2014). “I am working-class.” Educational Researcher, 43, 196-200.

Sears, D. \& Savelei, V. (2006). The political color line in America. Political Psychology, 27, 895-924.

Skeggs, B. (2004). Class, self, culture. NY: Routledge.

Smith, T., Marsden, P. \& Hout, M. (2011). General Social Survey. Ann Arbor: ICPSR.

Stephens, N.M., Markus, H.R., \& Fryberg, S.A. (2012). Social class disparities in health and education. Psychological Review, 119, 723-744.

Thompson, F. (1988). The rise of respectable society. Cambridge: Harvard.

Thompson, J., and Suarez, G. (2015). Exploring the Racial Wealth Gap Using the Survey of Consumer Finances. Washington: Federal Reserve.

Twenge, J. \& Crocker, J. (2002). Race and self-esteem. Psychological Bulletin, 128, 371-408.

Wang, W. (2012). The rise of intermarriage. Washington: Pew.

Wilson, W.J. (1990). The truly disadvantaged. Chicago: Chicago.

Wouters, C. (2007). Informalization. London: Sage.

Yuki, M. (2003). Intergroup comparison versus intragroup cooperation. Social Psychology Quarterly, 66, 166-183. 
